Gut, 1986, 27, 386-391

Alimentary tract and pancreas

\title{
Kinetics of lymphocyte subpopulation in intestinal mucosa of protein deficient Giardia lamblia infected mice
}

\author{
PARVATI UPADHYAY, N K GANGULY, B N S WALIA, AND R C MAHAJAN \\ From the Departments of Parasitology and Paediatrics Postgraduate Institute of Medical Education and \\ Research, Chandigarh, India
}

SUMMARY Kinetics of gut lymphocyte subpopulations were studied in normal and malnourished groups of mice infected with Giardia lamblia. The maximum parasite load was observed at second, third, and first week of postinfection in normal controls, moderate (8\%) and severe (3\%) protein deficient groups respectively. The number of $G$ lamblia trophozoite in $3 \%$ protein deficient group was low compared with control groups. A significant increase in $\mathrm{T}$ cell population of intraepithelial lymphocytes and lamina propria in normal and moderate protein deficient groups was observed with the development of infection. It was less marked, however, in the severely malnourished group. Interplay of mucosal immune status with nutrition and G lamblia infection is discussed.

Infection with Giardia lamblia in man sometimes results in diarrhoea and malabsorption. ${ }^{1}$ Histopathological abnormalities ${ }^{2}$ such as mild villous atrophy with mononuclear cell infiltration and decrease in the villous crypt ratio in small intestine have been reported. The infection is more severe in malnourished $^{3}$ or hypogammaglobulenaemic children. ${ }^{1}$ Wright et $a l^{4}$ reported that the degree of malabsorption is dependent on the intraepithelial lymphocyte counts. They did not, however, study the nutritional status of these subjects. Protein deficiency is known to increase the risk of infection ${ }^{5}$ probably through its deleterious effect on the host's humoral and cellular responses. ${ }^{6}$ Ganguly et $a l^{7}$ reported no change in the splenic $T$ lymphocytes but an increase in B lymphocytes in a mouse model established for $G$ lamblia infection. ${ }^{8}$ The recovery from $G$ lamblia infection correlated with the splenic $\mathrm{T}$ cell number in thymectomised mice. Increased intraepithelial lymphocyte counts in the mice infected with $G$ muris have been reported. ${ }^{9}$ As lymphocytes in $G$ lamblia infection have been both linked with immunity and pathogenesis, there is need to examine the mucosal immune status in normal and immunosuppressed giardia infected mice.

Address for correspondence: Professor R C Mahajan. Head, Department of Parasitology. Postgraduate Institute of Medical Education and Research. Chandigarh-160012, India.

Received for publication 1 August 1985.
In the present study, an effort has been made to study the lymphocyte subsets in intestinal epithelium and lamina propria of normal and protein deficient mice infected with $G$ lamblia.

\section{Methods}

ANIMALS AND GROUPS

Two weeks old, closely bred infection free Swiss albino mice, reared in the Central Animal House of the Postgraduate Institute of Medical Education and Research, Chandigarh, India, were used for the study. They were fed with a commercially prepared diet for five days in the laboratory and then divided into experimental and control groups.

The experimental groups were given $8 \%$ and $3 \%$ protein deficient isocaloric diets and were pair fed with control $(18 \%)$ diet. Details of the diet have been given elsewhere. ${ }^{10}$ The animals were divided into four groups of 30 animals each: (1) Eight per cent protein deficient group (moderate); (2) Pair fed control group of $8 \%$; (3) Three per cent protein deficient group (severe); (4) Pair fed control group of $3 \%$.

INFECTION OF MICE WITH G LAMBLIA

$G$ lamblia cysts were obtained from stool samples from a patient admitted to the Nehru Hospital attached to the Postgraduate Institute of Medical Education and Research, Chandigarh. These were 
purified on a sucrose density gradient ${ }^{11}$ and were adjusted to 10000 cysts per $0 \cdot 2 \mathrm{ml}$ inoculum. These cysts were used to infect all the control and experimental animals.

The experimental animals were fed on a protein deficient diet and the establishment of protein deficiency was checked by the level of serum albumin. As a significant $(\mathrm{p}<0 \cdot 01)$ drop in serum albumin (Figure) was seen in the $8 \%$ protein deficient group at two weeks, all the animals and their controls were infected at this time with $G$ lamblia cysts. The age of the experimental and control mice at the time of infection was five weeks. Five animals of each group were killed at weekly intervals for studying the lymphocyte subsets at gut level up to five weeks postinfection.

\section{GIARDIA CYSTS/TROPHOZOITES COUNTS}

A two hours stool sample was collected from infected mice before being killed and $G$ lamblia cysts were counted. The trophozoites were counted from intestinal perfusate of infected mice obtained by flushing the small intestine (pyloroduodenum and ileocaecal region) repeatedly with a syringe under pressure with a fixed volume $(5 \mathrm{ml})$ of ice cold saline. ${ }^{8-10}$ The chilled saline helps in the detachment of Giardia attached to the mucosal surface. ${ }^{12}$ The perfusate was pooled, centrifuged, and brought to one millilitre volume. The trophozoites were counted in a haemocytometer and expressed as number of trophozoites per millilitre of perfusate.

PURIFICATION OF LYMPHOCYTES

The lymphocytes from epithelium and lamina

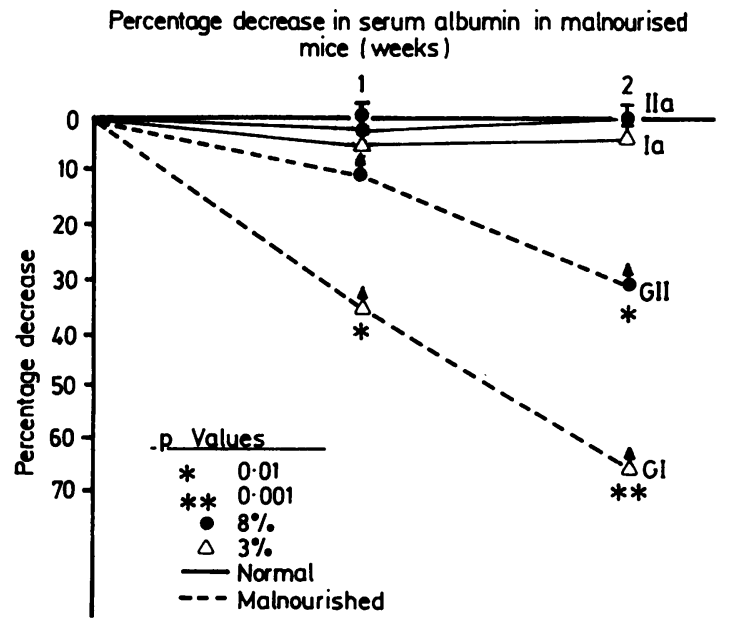

Figure Per cent decrease in serum albumin in malnourished mice ( $g / d l)$. propria of small intestine were purified by modified methods of Davies and Parrott ${ }^{13}$ and Tagliabue et al. ${ }^{14}$

For intraepithelial lymphocytes, the small intestine between the pyloroduodenum and ileocaecal region was removed and thoroughly washed with cold minimal essential medium (MEM) to remove food particles. The cleaned intestine was then spread on moistened filter paper to remove the Peyer's patches, blood vessels, and mesentery. It was opened longitudinally into small pieces. These pieces were treated with dithioerythritol and incubated at $37^{\circ} \mathrm{C}$ for 15 minutes in MEM containing $5 \mathrm{mmol}$ of EDTA with constant stirring. The process was repeated thrice. The supernatants were pooled, centrifuged, resuspended in RPMI-5\% fetal calf serum filtered through glass wool column and washed. Most of the lymphocytes obtained by this method were from epithelial cells. ${ }^{13}$

The remaining gut pieces were processed for purification of lymphocytes from lamina propria. The gut pieces were washed with MEM and incubated for 20 minutes in RPMI-5\% fetal calf serum to inactivate any remaining EDTA. These were then incubated with collagenase $(25 \mathrm{U} / \mathrm{ml})$ in RPMI-5\% fetal calf serum at $37^{\circ} \mathrm{C}$ for 80 minutes with stirring. The supernatant was filtered through glass wool column and cells were washed twice with medium.

For further purification, the suspension from intraepithelium and lamina propria preparations were loaded separately on percoll density gradient ${ }^{13}$ and centrifuged at $600 \mathrm{~g}$ for 20 minutes at $4^{\circ} \mathrm{C}$. Lymphocyte rich preparation was recovered from $1 \cdot 050 / 1 \cdot 085 \mathrm{~g} / \mathrm{ml}$ density interface.

Our methods and those of Davies and Parrott ${ }^{13}$ and Tagliabue et al ${ }^{14}$ were compared for relative yield of intraepithelial lymphocytes (IEL). The IEL yield by our method was $6 \times 10^{6}-2 \cdot 1 \times 10^{7}$ cells/mouse small intestine whereas by the Davies and Parrott ${ }^{13}$ method, it was $9 \times 10^{6}-1.8 \times 10^{7}$ and the Tagliabue $e t$ $a l^{14}$ method $5-10 \times 10^{6}$ cells. The range indicates results obtained in five animals.

The viability of the lymphocytes was checked with $0.2 \%$ trypan blue. The cells were counted in a haemocytometer. On an average, more than $95 \%$ cells obtained were viable.

ESTIMATION OF INTRAEPITHELIAL LYMPHOCYTES AND LAMINA PROPRIA LYMPHOCYTES

$T$ and $B$ cells were counted by the method described by Gravely et al ${ }^{15}$ and Ganguly et $a l^{7}$ Briefly the T lymphocytes were quantified by a cytotoxic method, and antithymocyte serum was prepared according to Skamerse. ${ }^{16} 7 \times 10^{8}$ Thymocytes of Swiss albino mice were injected into rabbits intravenously three times 
Table 1 Intraepithelial cells, lamina propria cell, cysts and trophozoite counts from normal and malnourished mice infected with $\mathrm{G}$ lamblia (mean $\pm S D$ ).

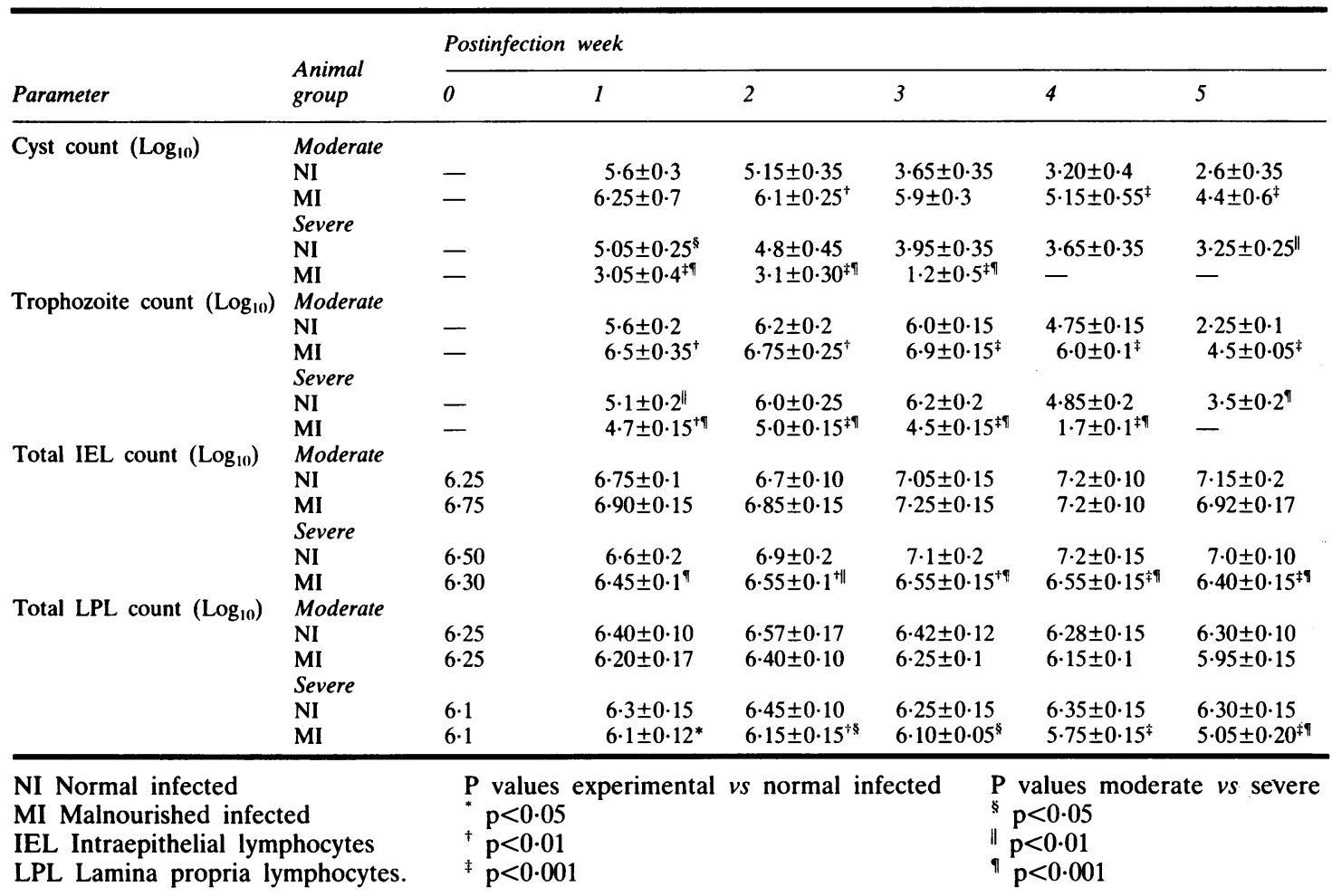

Table 2 Number of $T$ and B lymphocytes from epithelium from the intestine of normal and malnourished mice infected with $\mathrm{G}$ lamblia (lymphocytes/total length of small intestine).

\begin{tabular}{|c|c|c|c|c|c|c|c|c|}
\hline Sr no & Group lym & ocyte \% & 0 & 1 & 2 & 3 & 4 & 5 \\
\hline 1 & 8 & $\mathrm{~T}$ & $\begin{array}{l}4 \cdot 2 \pm 1 \cdot 1 \\
(71 \%) \\
0 \cdot 4 \pm 0 \cdot 09 \\
(6 \cdot 7 \%)\end{array}$ & $\begin{array}{l}5 \cdot 8 \pm 1 \cdot 5 \\
(71 \%) \\
0 \cdot 5 \pm 0 \cdot 09 \\
(7 \cdot 4 \%)\end{array}$ & $\begin{array}{l}6 \cdot 9 \pm 1 \cdot 8 \\
(72 \cdot 8 \%) \\
0 \cdot 8 \pm 0 \cdot 3 \\
(7 \cdot 6 \%)\end{array}$ & $\begin{array}{l}8 \cdot 6 \pm 1 \cdot 8 \\
(73 \cdot 8 \%) \\
0.9 \pm 0 \cdot 3 \\
(7 \cdot 9 \%)\end{array}$ & $\begin{array}{c}8 \cdot 7 \pm 2 \cdot 7 \\
(72 \cdot 4 \%) \\
1 \cdot 2 \pm 0 \cdot 4 \\
(7 \cdot 2 \%)\end{array}$ & $\begin{array}{l}7 \cdot 7 \pm 1 \cdot 6 \\
(71 \cdot 6 \%) \\
0 \cdot 9 \pm 0 \cdot 3 \\
(6 \cdot 5 \%)\end{array}$ \\
\hline \multirow[t]{2}{*}{2} & 8 pair fed & $\mathrm{T}$ & $\begin{array}{l}4 \cdot 5 \pm 1 \cdot 8 \\
(74 \%)\end{array}$ & $\begin{array}{l}6 \cdot 4 \pm 2 \cdot 7 \\
(78 \%)\end{array}$ & $\begin{array}{l}8 \cdot 1 \pm 1 \cdot 5 \\
(80 \cdot 4 \%)\end{array}$ & $\begin{array}{l}9.9 \pm 3.9 \\
(80 \cdot 2 \%)\end{array}$ & $\begin{array}{l}10 \cdot 9 \pm 3 \cdot 1 \\
(79 \cdot 8 \%)\end{array}$ & $\begin{array}{l}9 \cdot 5 \pm 3 \cdot 8 \\
(73 \cdot 4 \%)\end{array}$ \\
\hline & & B & $0.4 \pm 0.06$ & $0 \cdot 7 \pm 0.12$ & $0 \cdot 8 \pm 0 \cdot 3$ & $0.8 \pm 0.02$ & $0.95 \pm 0.03$ & $0.93 \pm 0.4$ \\
\hline \multirow[t]{2}{*}{3} & 3 & $\mathrm{~T}$ & $\begin{array}{l}2 \cdot 07 \pm 1 \cdot 6 \\
(64 \%)\end{array}$ & $\begin{array}{l}3 \cdot 2 \pm 0 \cdot 8 \\
(57 \cdot 6 \%)\end{array}$ & $\begin{array}{l}3 \cdot 3 \pm 0 \cdot 7 \\
(55 \cdot 8 \%)\end{array}$ & $\begin{array}{l}3 \cdot 6 \pm 1 \cdot 2 \\
(50 \cdot 4 \%)\end{array}$ & $\begin{array}{l}3 \cdot 2 \pm 0 \cdot 8 \\
(49 \cdot 6 \%)\end{array}$ & $\begin{array}{l}1 \cdot 9 \pm 0 \cdot 6 \\
(40 \cdot 2 \%)\end{array}$ \\
\hline & & B & $\begin{array}{l}0 \cdot 2 \pm 0 \cdot 04 \\
(5 \cdot 7 \%)\end{array}$ & $\begin{array}{l}0 \cdot 3 \pm 0 \cdot 03 \\
(5 \cdot 4 \%)\end{array}$ & $\begin{array}{l}0 \cdot 3 \pm 0 \cdot 09 \\
(4 \cdot 2 \%)\end{array}$ & $\begin{array}{l}0.4 \pm 0 \cdot 02 \\
(4 \cdot 0 \%)\end{array}$ & $\begin{array}{l}0 \cdot 2 \pm 0 \cdot 01 \\
(3 \cdot 6 \%)\end{array}$ & $\begin{array}{l}0 \cdot 2 \pm 0 \cdot 06 \\
(3 \cdot 5 \%)\end{array}$ \\
\hline \multirow[t]{2}{*}{4} & 3 pair fed & $\mathbf{T}$ & $\begin{array}{l}3 \cdot 4 \pm 1 \cdot 2 \\
(65 \cdot 6 \%)\end{array}$ & $\begin{array}{l}4 \cdot 0 \pm 1 \cdot 5 \\
(65 \cdot 8 \%)\end{array}$ & $\begin{array}{l}7 \cdot 6 \pm 1 \cdot 8 \\
(71 \cdot 6 \%)\end{array}$ & $\begin{array}{l}8 \cdot 5 \pm 3 \cdot 4 \\
(72 \cdot 2 \%)\end{array}$ & $\begin{array}{l}10 \cdot 2 \pm 2 \cdot 8 \\
(74 \cdot 6 \%)\end{array}$ & $\begin{array}{l}8 \cdot 2 \pm 1 \cdot 3 \\
(72 \cdot 6 \%)\end{array}$ \\
\hline & & B & $\begin{array}{l}0 \cdot 4 \pm 0 \cdot 02 \\
(6 \cdot 5 \%)\end{array}$ & $\begin{array}{l}0.5 \pm 0.07 \\
(7 \cdot 2 \%)\end{array}$ & $\begin{array}{l}0.7 \pm 0.05 \\
(7.4 \%)\end{array}$ & $\begin{array}{l}8 \cdot 9 \pm 0 \cdot 26 \\
(7 \cdot 3 \%)\end{array}$ & $\begin{array}{l}0.94 \pm 0 \cdot 06 \\
(7 \cdot 2 \%)\end{array}$ & $\begin{array}{l}0.8 \pm 0.04 \\
(6 \cdot 8 \%)\end{array}$ \\
\hline
\end{tabular}

The figures denote number of lymphocytes $\left(10^{6}\right)$ and the parentheses denote percentage lymphocytes. 
at 10 days intervals. Antithmocyte serum was absorbed with mouse erythrocytes, liver homogenate, agarose, $2 \times 10^{6}$ glass adhering cells and EAC rosetting mouse lymphocytes by keeping them at $37^{\circ} \mathrm{C}$ for one hour and then over night at $4^{\circ} \mathrm{C}$. The specificity of antithymocyte serum was checked by a cytotoxicity test using trypan blue exclusion method with antithmocyte serum and absorbed guinea pig serum as a source of complement, mouse monocytes (glass adherences) and mice EAC rosetting cells (EAC rosetting cells were obtained by separating the B lymphocytes on Ficoll gradient column after rosetting and lysing the RBCs with tris ammonium chloride solution), $\mathrm{T}$ cells by (nylon separation method) and were incubated at $37^{\circ} \mathrm{C}$ for 45 minutes. The percentage of viable cells was obtained from a total of 200 cells. Cytotoxicity was more than $95 \%$ for glass adhering cells and less than $5 \%$ for EAC rosetting cells.

The $\mathrm{B}$ cells were quantified by a rosetting technique. ${ }^{17}$ The cells were treated with sensitised sheep red blood cells and mouse serum as a source of complement. These were incubated at $37^{\circ} \mathrm{C}$ for 30 minutes and then centrifuged at $500 \mathrm{rpm}$ for five minutes. The rosettes and lymphocytes were counted in 200 cells to calculate the percentage of $B$ rosettes in the cell suspension. Peripheral blood lymphocytes were treated with the same concentration of DTT, EDTA and collagenase as in the gut, and the values for untreated and treated $B$ and $T$ cells were within $5 \%$ error range.

\section{STATISTICAL METHOD}

Statistical analysis was carried out with Student's $t$ test and the data have been expressed as mean \pm SD. Analysis of variance has been carried out for a significance of changed lymphocytes within the group and time.

\section{Results}

The Figure shows the pattern of serum albumin concentrations in animals on $3 \%, 8 \%$, and normal protein diet. By the end of the second week, the decrease in albumin concentration was significant $(p<0.01)$ in animals fed on the $8 \%$ protein diet and highly significant in those given the $3 \%$ protein diet $(\mathrm{p}<0.001)$.

Table 1 shows the cysts, trophozoites, and absolute lymphocyte counts from epithelium and lamina propria of $G$ lamblia infected animals. Higher cyst and trophozoite counts were observed in the $8 \%$ protein fed animals as compared with their pair fed controls $(p<0 \cdot 01)$. In contrast a significant decrease was observed in the $3 \%$ protein fed animals as compared with its pair fed group. An increase in the epithelial lymphocytes of moderate and its pair fed infected controls was observed but intergroup difference was not significant. The count was, however, significantly lower in the $3 \%$ protein fed infected animals than in their pair fed control. The absolute counts of the lamina propria lymphocytes are slightly lower in the moderate deficient groups whereas in the severe deficient one it was significantly lower when compared with their respective controls.

The average baseline values of intraepithelial $\mathrm{T}$ cell population obtained from normal, $8 \%$, and 3\% protein fed animals were $4 \cdot 9 \pm 2 \cdot 1,4 \cdot 2 \pm 1 \cdot 1$ and $2.07 \pm 1.6$ respectively. The figures for lamina propria $T$ cells were $2 \cdot 5 \pm 0 \cdot 7,2 \cdot 1 \pm 0.6$ and $1.9 \pm 0.9$ respectively. Similarly, the basal values for B cells of intraepithelial population in normal, $8 \%$ and $3 \%$ protein fed animals were $0.98 \pm 0.4,0.68 \pm 0.21$ and $0 \cdot 29 \pm 0 \cdot 20$ respectively and in lamina propria these were $0.35 \pm 0.27,0.30 \pm 0.2$ and $0.1 \pm 0.06$ respectively.

Table 2 shows the number of $\mathrm{T}$ and $\mathrm{B}$ lymphocytes in the epithelium of different infected groups. An upward trend was observed in moderate protein deficient infected animals and pair fed controls of both $8 \%$ and $3 \%$ protein fed animals. These values were higher compared with their basal values. The T and $\mathrm{B}$ lymphocytes in the $8 \%$ protein fed animals were high up to the fourth week and thereafter a decrease was observed. In severe deficiency, a slight increase in the T and B cells of the pair fed controls and consistent decrease in the $3 \%$ protein fed infected animals was observed.

Table 3 shows the analysis of variance for intraepithelial $\mathrm{T}$ lymphocytes. A significant difference was observed between the groups and time $(\mathrm{p}<0.001$ and $\mathrm{p}<0.01$ respectively). Group 3 (severe deficiency) showed significant low values $(\mathrm{p}<0.01)$ compared with other groups where a significant decrease $(p<0.05)$ in $T$ lymphocytes was observed in the second and third postinfection weeks. For B lymphocytes (Table 3), a significant difference has been observed between the groups and time ( $p<0.001$ and $p<0.01$ respectively). Group 3 has been observed to have a significantly low value $(p<0.01)$ compared with the other groups. No change was noticed in intraepithelial B lymphocytes of protein deficient groups from their respective pair fed controls.

The pattern of $\mathrm{T}$ and $\mathrm{B}$ lymphocytes of lamina propria is shown in the Table 4 . In the $8 \%$ pair fed group the peak $T$ lymphocyte count was on the second week postinfection after which an insignificant decrease was observed. In contrast in severe deficiency a downward trend was observed until the end of study. 
Table 3 Analysis of variance for epithelial T lymphocytes

\begin{tabular}{lcccc}
\hline Source & $S S$ & $D F$ & $M S$ & $F$ \\
\hline Group & $330 \cdot 3$ & 3 & $110 \cdot 1$ & $2 \cdot 4^{*}$ \\
Time & $9338 \cdot 5$ & 5 & $1867 \cdot 7$ & $41 \cdot 23^{*}$ \\
Replication & 54.39 & 4 & $13 \cdot 74$ & \\
Error & 4852.9 & $10 \cdot 7$ & $45 \cdot 35$ & \\
\hline
\end{tabular}

$P$ values $={ }^{*}<0 \cdot() 1$

Table 4 Analysis of variance for epithelial B lymphocytes

\begin{tabular}{lrrrl}
\hline Source & \multicolumn{1}{c}{$S S$} & $D F$ & \multicolumn{1}{c}{$M S$} & $F$ \\
\hline Group & $285 \cdot 5$ & 5 & $57 \cdot 1$ & $285^{*}$ \\
Time & $27 \cdot 7$ & 3 & $9 \cdot 2$ & $4 \cdot 6$ \\
Replication & $53 \cdot 4$ & 4 & $13 \cdot 3$ & \\
Error & $218 \cdot 2$ & 108 & $2 \cdot(12$ & \\
Total & $584 \cdot 8$ & 120 & $81 \cdot 6$ & \\
\hline P & & & &
\end{tabular}

$P$ values $={ }^{*}<0 \cdot(01$

Analysis of variance for lamina propria $T$ cells showed a significant difference between the groups and time $(\mathrm{p}<0.001)$ and $(\mathrm{p}<0.01$ respectively). Group 3 had significantly low values $(p<0 \cdot 01)$ compared with other groups. A significant decrease $(\mathrm{p}<0.05)$ in $\mathrm{T}$ lymphocytes was seen in the third and fourth weeks. For B cells, group 3 showed a significantly low value $(p<0.01)$ compared with other groups from the second week onwards.

\section{Discussion}

Results of the present study have shown that the mucosal lymphocytes in the intraepithelial cells were predominantly $\mathrm{T}$ cells whereas in the lamina propria they were a mixture of $\mathrm{T}$ and $\mathrm{B}$ cells. We detected approximately $6 \%$ B lymphocytes in the epithelial cells and about $13 \%$ B lymphocytes in the lamina propria. By a similar isolation technique, Lyscom and Bruton ${ }^{18}$ obtained $0.6 \%$ B lymphocytes in the epithelial cells and $28 \%$ B lymphocytes in the lamina propria. They had carried out the study with monoclonal antibody whereas we used rosetting technique for detection of B lymphocytes. This technique might give some false positive and negative reactions but because it was longitudinal the same variation will be reflected throughout the study.

The number of intraepithelial and lamina propria lymphocytes increased during the course of infection both in normal and $8 \%$ protein fed animals. This increase was mainly in the $\mathrm{T}$ cells, although the quantum of increase was much less in the latter group. A similar increase in lymphocyte population was also seen in jejunal biopsy specimens of human $^{4}{ }^{19}$ and murine giardiasis. ${ }^{9}$ The lymphocyte subpopulations were not identified, however.

A concomitant decrease in the trophozoite counts in normal and $8 \%$ protein fed animals was observed together with the rise in $\mathrm{T}$ lymphocytes in the gut. The elimination of the parasite in the $8 \%$ protein group was delayed.

The $3 \%$ protein fed animals behaved differently; in these a marked decrease in intraepithelial and lamina propria $\mathrm{T}$ lymphocytes was seen as was also observed by Maffei et al. ${ }^{20}$ After infection, in contrast with other groups, there was no increase in the gut lymphocytes thereby indicating a low degree of immunoreactivity at the gut level in these animals. Unlike the $8 \%$ protein fed group, where slightly low $\mathrm{T}$ lymphocytes were seen in comparison

Table 5 Number of $T$ and B lymphocytes from lamina propria from the intestine of normal and malnourished mice infected with $\mathrm{G}$ lamblia (lymphocytes/total length of small intestine).

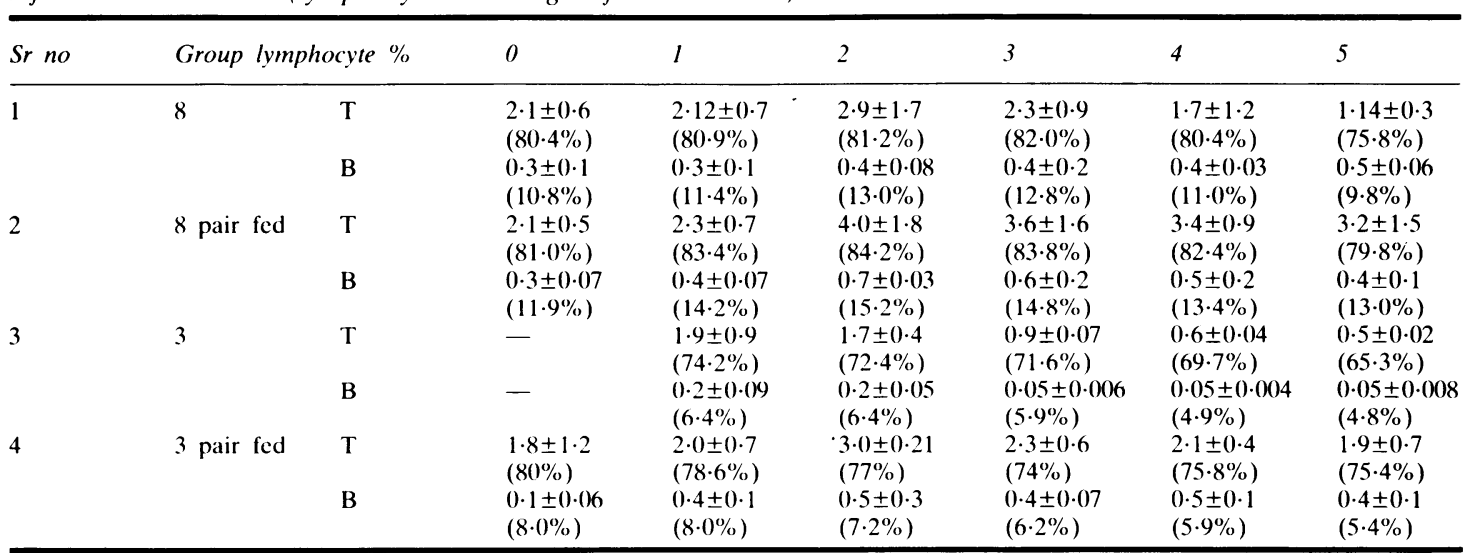

The figures denote number of lymphocytes $\left(10^{6}\right)$ and the parentheses denote percentage lymphocyte. 
with the normal group, and trophozoites increased in number for a longer period, in the $3 \%$ protein fed group with significantly low gut lymphocytes the trophozoite counts remained low. This could be because of severe protein deficiency in this group. We have shown earlier (unpublished data) that in the severe deficiency group although the number of trophozoites was low the tissue invasion of the small intestine by the trophozoites was quite marked. This again indirectly substantiates the role of gut lymphocytes in the immunity to giardia infection. We have shown that gut lymphocytes are cytotoxic to $G$ lamblia trophozoites. ${ }^{21}$

\section{References}

1 Ament ME, Rubin CE. Relation of giardiasis to abnormal gastrointestinal structure and functions in gastrointestinal immuno-deficiency syndrome. Gastroenterology 1972; 62: 216-26.

2 Brandborg LL, Tankersley CB, Gottlieb S, Barancik S, Sartor VE. Histological demonstration of mucosal invasion by Giardia lamblia in man. Gastroenterology 1967; 52: 143-50.

3 Gracey M. Enteric disease in young Australian aborigines. Aust $N Z$ J Med 1973; 3: 576-9.

4 Wright SG, Tomkins AM. Quantification of the lymphocytic infiltrate in jejunal epithelium in giardiasis. Clin Exp Immunol 1977; 29: 408-12.

5 Scrimshaw NS. Interaction of nutrition and infection. Am J Med Sci 1959; 237: 367-3.

6 Bell RG, Hazell LA, Price P. Influence of dietary protein restriction on immune competence II. Effect on lymphoid tissue. Clin Exp Immunol 1976; 26: 314-20.

7 Ganguly NK, Vasudeva V, Anand BS, Dilawari JB, Chandnani RE, Mahajan RC. A study of lymphocyte subpopulation in normal and thymectomised mice infected with G lamblia. Ann Trop Med Parasitol 1981; 75: 347-51.

8 Vasudeva V, Ganguly NK, Anand BS, Radhakrishna VR, Dilawari JB, Mahajan RC. A study of giardia infection in irradiated and thymectomised mice. J Trop Med Hyg 1982; 82: 314-9.
9 McDonald TT, Ferguson A. Small intestinal epithelial cell kinetics and protozoal infection in mice. Gastroenterology 1978; 74: 496-500.

10 Parvati Upadhyay, Ganguly NK, Mahajan RC, Walia BNS. Intestinal uptake of nutrients in normal and malnourished animals infected with Giardia lamblia. Digestion 1985 32: 243-8.

11 Roberts-Thomson IC, Stvens DP, Mahmoud AAF, Warren KS. Giardiasis in the mouse: an animal model. Gastroenterology 1976; 71: 57-61.

12 Feely DE, Erlandsen S. Isolation and purification of giardia trophozoites from rat intestine. J Parasitol 1981; 67: $59-64$.

13 Davies MDJ, Parrott DMV. Preparation and purification of lymphocytes from the epithelium and lamina propria of murine small intestine. Gut 1981; 22: 481-8.

14 Tagliabue A, Befus AD, Clark DA, Bienenstock J. Characteristics of natural killer cells in the murine intestinal epithelium and lamina propria. J Exp Med 1982; 155: 1785-96.

15 Gravely SM, Hamburger J, Kreier JP. T and B cell population changes in young and adult rats infected with Plasmodium berghei. Infect Immun 1976; 14: 178-83.

16 Skamerse S. Antilymphocyte serum binding to cell surface. Fed Proc 1970; 29: 126-8.

17 Jondhall M, Holm G, Wizele M. Surface markers on human $T$ and $B$ lymphocytes. A large population of lymphocytes forming non-immune rossettes with sheep red blood cells. J Exp Med 1972; 136: 207-15.

18 Lyscom N, Bruton MJ. Intraepithelial, lamina propria and Peyer's patch lymphocytes of the rat small intestine, isolation and characterisation in terms of immunoglobulins markers and receptors for monoclonal antibodies. Immunology 1982; 45: 775-83.

19 Ferguson A, McClure JP, Townley RR. Intraepithelial lymphocyte counts in small intestinal biopsies from children with diarrhoea. Acta Paediatr Scand 1976; 65: 541-8.

20 Maffei HVL, Rodrigues MAM, Camargo JLUDC, Compana AD. Intraepithelial lymphocytes in jejunal mucosa in malnourished rats. Gut 1980; 21: 32-6.

21 Kanwar SS, Ganguly NK, Walia BNS, Mahajan RC. Direct and antibody dependent cell mediated cytotoxicity against Giardia lamblia by splenic and intestinal lymphoid cells in mice. Gut 198526 (in press). 